2014

\title{
International Human Rights in Canada: At the Juncture of Law and Politics
}

Faisal Bhabha

Osgoode Hall Law School of York University, fbhabha@osgoode.yorku.ca

Follow this and additional works at: http:// digitalcommons.osgoode.yorku.ca/olsrps

\section{Recommended Citation}

Bhabha, Faisal, "International Human Rights in Canada: At the Juncture of Law and Politics" (2014). Osgoode Legal Studies Research Paper Series. 55.

http://digitalcommons.osgoode.yorku.ca/olsrps/55 


\section{OSGOODE}

OSGOODE HALL LAW SCHOOL

YOR K U N I VERSITY

\section{OSGOODE HALL LAW SCHOOL}

LEGAL STUDIES RESEARCH PAPER SERIES

Research Paper No. 17/2014

Vol. 10, No. 5 (2014)

International Human Rights in Canada: At the Juncture of Law and Politics

Working Paper

Faisal Bhabha

\section{Editors:}

Peer Zumbansen (Osgoode Hall Law School, Toronto; Canada Research Chair in Transnational Economic Governance and Legal Theory - Editor in Chief)

Stephen Ji (Osgoode Hall Law School, Toronto - Production Editor) 
Vol. 10, No. 5 (2014)

\title{
International Human Rights in Canada: At the Juncture of Law and Politics
}

\author{
Working Paper
}

Faisal Bhabha

\begin{abstract}
:
This paper addresses the topic of international human rights law from the Canadian perspective. As the title suggests, this paper's analysis of the topic sits at the intersection of law and politics, where all questions of international law necessarily do. It proceeds in three parts. First, it provides a sketch of the political context, drawing from recent events and trends, to describe a conflicted official government approach to international human rights. Next, it examines the formal legal status of international human rights law in Canada, drawing selectively from Supreme Court of Canada jurisprudence. Finally, it addresses the adoption of the newest international human rights treaty, the Disability Convention, and discusses calls to promote access to justice at the international level for breaches of Convention norms domestically. Notwithstanding important efforts to advance the status of international human rights law in Canada, the author's overall observation is that, in both law and politics, the Canadian approach to international human rights is predominantly inward looking.
\end{abstract}

\section{Keywords:}

International law, human rights, Supreme Court of Canada, Disability Convention, law and politics

\section{Author(s):}

Faisal Bhabha

Assistant Professor

Osgoode Hall Law School

York University, Toronto

E: fbhabha@osgoode.yorku.ca 


\title{
International Human Rights in Canada: At the Juncture of Law and Politics
}

\author{
Faisal Bhabha*
}

\section{Introduction}

This paper addresses the timely topic of international human rights law from the Canadian perspective. As the title suggests, this paper's analysis of the topic sits at the intersection of law and politics, where questions of international law necessarily do. It proceeds in three parts. First, it will provide a sketch of the political context, drawing from recent events and trends, to describe a conflicted official government approach to international human rights. Next, it will examine the formal legal status of international human rights law in Canada, drawing selectively from Supreme Court of Canada jurisprudence. Finally, it will address the recent adoption of the newest international human rights treaty, the Disability Convention, and discuss calls to promote access to justice at the international level for breaches of Convention norms domestically. Notwithstanding important efforts to advance the status of international human rights law in Canada, my overall observation is that, in both law and politics, the Canadian approach to international human rights is predominantly inward looking.

\section{Human Rights: From Moral Aspiration to Discursive Dominance}

It is worth beginning with the moral origins that underlie the legal and institutional apparatus that forms the international human rights system. Buoyed by developments during the post-WWII period in Europe, the contemporary conception of human rights blossomed from the fields of corpses, through the smoke of gas chambers. According to the Charter of the UN, adopted in 1945, the purpose of international organization was to "save succeeding generations from the scourge of war". ${ }^{1}$ The dominant global actors at the time believed that the world had seen the worst of human evil, and in the face of the failure of politics to protect humanity from itself, they turned to the law. The birth of international human rights law thus came as a response to, if not penance for, the wrongs of war.

But international human rights have found a space, politically and doctrinally, separate from the laws of war. The important work of human rights has been to

\footnotetext{
* Assistant Professor and Faculty Advisor to the International Legal Partnerships Program, Osgoode Hall Law School of York University. Toronto, Canada. This paper is modified from remarks delivered to the International Association of Law Librarians' Conference, on October 1, 2012, in Toronto and published as "International Human Rights in Canada: At the Juncture of Law and Politics" (2013) 41(1) Int'l J Legal Info 1. The author expresses gratitude to the Association and to the many members who provided invaluable feedback on the remarks.
}

${ }^{1}$ Charter of the United Nations, June 26, 1945, 59 Stat 1031, TS 993, 3 Bevans 1153, entered into force Oct 24, 1945. 
establish a normative framework for ensuring the advancement of individual human security and dignity during peacetime, under civilian political leaders who are subject to limits on their power. From the Universal Declaration on Human Rights to the twin pillar Covenants, to the various Conventions dealing with women's rights, racial discrimination and children's rights, the scope of human rights continues to evolve, extending wide across the different spheres of human experience.

For this reason, defining human rights for the purpose of any discussion is an important starting point. One obvious meaning of international human rights is to equate it with international human rights law, as I have done. But human rights represents more than positive law. It describes values and goals that are meant to embody moral norms, many of which are held across different societies. The hope of universalism has meant that human rights not only describe existing norms, but also create new standards of conduct and accountability. These standards have spread the world over.

The spread of human rights has generated its share of response and resistance. ${ }^{2}$ Indeed, the aspiration of universality has been matched by the disappointment of inconsistency. The political failures to rationalize inadequate rights protection in the West, has undermined the legitimacy and appeal of the human rights project in the global South, with many seeing human rights as an extension of Western economic, political and cultural dominance, and even as a form of neo-imperialism.

Human rights scepticism grows from the questions that remain on many fronts regarding the content, shape and form of human rights law. For example, how a specific human rights goal or value is defined, interpreted and enforced is highly contingent on external factors, especially where implementation of the right will impact established behaviours or vested interests. The state-centric model of international law has made the work of activist and victims groups largely focused on trying to convince state governments to take action. It means human rights claimants must not only have justice on their side; they must also be politically savvy. The frustrated struggles to enforce human rights have thus revealed the limits of human rights possibilities. The law's ambition is tethered to realpolitik constraints. As one prominent commentator noted, "human rights may be universal, but support for coercive enforcement of their norms will never be universal." ${ }^{3}$

Human rights advocates the world over have learned through experience, that success in achieving human rights remedial action has as much to do with having the means, ability and access to make a claim, as it does with the substantive merit of the claim. The process of rights contestation-that is, the struggles to define what a human right means and whether and how it will be enforced in any given

\footnotetext{
${ }^{2}$ See Makau Mutua, Human Rights: A Political and Cultural Critique (Philadelphia: U Penn Press, 2008).

3 Michael Ignatieff, Human Rights as Politics and Idolatry (Princeton: Princeton, U Press, 2003) at 43.
} 
context-is at least as much an economic and political question as a legal one. So it goes: While the rhetorical power of human rights vindicates our moral intuitions, the real power of rights lies in having the material and institutional capacity to define, deploy and decide the law.

\section{Rights and Politics}

The rise to discursive dominance of human rights has led, both, to increasing resort to human rights language to describe a wide variety of personal and group grievances, as well as to using human rights language to justify assertions of state power. In international political disputes, we have seen human rights justifications on both sides of conflicts: the invasion of Iraq was justified by some, ${ }^{4}$ and opposed by others ${ }^{5}$ (including the United Nations) ${ }^{6}$ in part for reasons of international human rights. Examples like this demonstrate that the political nature of human rights is as much an important descriptive frame to consider as is the legal or doctrinal aspect, in order to have a complete picture. Indeed, the political nature of law is never quite so pronounced as it is in the realm of international law.

In Canada, the current government, in power since 2006, has had an ambivalent relationship with international human rights. It has earned scorn for leading Canada away from its record as a leader and consensus builder in international diplomacy, turning Canada into an outlier on key human rights issues. ${ }^{7}$ Domestically, the federal government has also been criticized for cuts to social programs, intrusive national security enforcement, an overly "tough on crime" strategy, and a callous approach to immigration and multiculturalism.

What makes this intriguing is that, at the same time, the government views itself, and holds itself out, as a champion of human rights. Just last week, Canada's Prime Minister, Stephen Harper, was presented with the World Statesman of the Year award. ${ }^{8}$ The award came from the Appeal of Conscience Foundation, a US-based "interfaith" group that "believes that freedom, democracy and human rights are the

\footnotetext{
4 See, e.g., Ed Morgan, "Use of force against Iraq is legal" National Post (March 19, 2003).

5 The overwhelming majority of opinions of international law scholars and jurists was that the invasion was illegal. See Severin Carrell and Robert Verkaik, "War on Iraq was Illegal, Say Top Lawyers" The Independent (May 25, 2003).

6 The American-led invasion was never authorized by the United Nations. In September 2004, thenSecretary General Kofi Annan publicly declared that the invasion had been "illegal". See Ewen MacAskill and Julian Borger, "Iraq war was illegal and breached UN charter, says Annan" The Guardian (16 September 2004).

${ }^{7}$ See, e.g., Getting Back on the 'Rights' Track: A Human Rights Agenda for Canada (Ottawa: Amnesty International Canada, 2011) [noting that Canada's standing as an international human rights champion has dropped during the Harper years, both in the international realm and in ensuring human rights domestically].

${ }^{8}$ Campbell Clark, "Harper honoured in N.Y. as statesman of the year, aims to snub UN" The Globe and Mail (September 11, 2012).
} 
fundamental values that give nations of the world their best hope for peace, security and shared prosperity." Presented with the award by former U.S. Secretary of State, Henry Kissinger, Harper spoke of Canada's "ancient heritage and long practice of freedom, democracy, human rights and the rule of law."10

The Prime Minister went on to describe the present state of the world as beset by insecurity, naming Iran as the chief source of mischief. Just earlier in the month, Canada had, without warning or reason, cut off diplomatic relations with the Islamic Republic. ${ }^{11}$ Calling Iran a "clear and present danger" to global security, Harper decried its "appalling record of human rights abuse". The solution, he said, is for the international community to do more to isolate Iran, and "to speak in support of the country that its hatred most immediately threatens, the State of Israel".

Harper's remarks were more than rhetorical seduction for an Israel-friendly audience; they reflected official and demonstrated government policy. Indeed, in recent years Canada has been Israel's most reliable ally on the world stage. This has been during a period when Israel's record on human rights garnered significant global outrage. ${ }^{12}$ In a 2011 report on the state of human rights in Canada, Amnesty International criticized the Canadian government for its "uneven" approach to the Middle East, noting Canada's "[u]nflinching refusal to raise concerns about the Israeli government's human rights record". ${ }^{13}$

In his speech to the Appeal of Conscience Foundation, Harper emphasized the importance of choosing friends carefully from among "like-minded" nations. One subtext of the Prime Minister's decision to turn down an opportunity to address the United Nations General Assembly in the same week, is that Canada has few friends left at the UN. The national media took note of the Prime Minister's UN "snub". ${ }^{14}$.,Even Conservative elders have rung the alarm: former Prime Minister,

\footnotetext{
${ }^{9}$ Appeal of Conscience Foundation, online: http://www.appealofconscience.org/about-us.cfm.

10 "Canadian Prime Minister Stephen Harper receives World Statesman Award at 2012 ACF Dinner" (September 27, 2012). Full text online: http://www.appealofconscience.org/news/article.cfm?id=100271.

${ }^{11}$ Campbell Clark, Patrick Martin and Mark Mackinnon, "Envoys out as Canada abruptly severs ties with Iran" The Globe and Mail (September 7, 2012)

12 Israel's bombing of Gaza, known as "Operation Cast Lead", in December 2008-January 2009 was the subject of a United Nations Fact-Finding Mission that concluded in its September 2009 report that numerous violations of international law occurred not only during the Israeli military's threeweek assault, but in the underlying conditions of the more than 40 year occupation of Palestinian territories.

${ }^{13}$ Getting back on the 'rights' track, supra at 4,14.

${ }^{14}$ Campbell Clark, "In accepting World Statesman award, Harper paints picture of uncertain world" The Globe and Mail (September 28, 2013).
} 
Brian Mulroney, and career diplomat, Paul Heinbecker, publicly worried about the government alienating Canada at the UN. ${ }^{15}$

On September 26-27, 2012, at the very same time that the Canadian Prime Minister was being feted as Statesman of the Year, the United Nations Committee on the Rights of the Child reported on its 10-year review of Canada's implementation of the Convention. ${ }^{16}$ The report chastised Canada for its approach to youth criminal justice, describing new legislation as "excessively punitive for children and not sufficiently restorative in nature". ${ }^{17}$ It further criticized cuts in Canadian social programs for children living in poverty, noting "serious and widespread discrimination" in the services provided to aboriginal children, visible minorities, immigrants and children with disabilities. ${ }^{18}$

These two images tell very different sides to the status of international human rights in Canada. On the one hand, the Prime Minister invokes human rights to stand on principle against an "immoral" state. On the other hand, Canada is found to be a human rights violator, abandoning its most vulnerable citizens. The contradiction is striking not just because Canada has traditionally been described as a prime defender of human rights globally. It is also striking in the sense that, while the current government continues to define its heritage and national goals in reference to human rights, the record suggests a string of failures and an atmosphere of open hostility to the very instruments and institutions designed to promote human rights domestically and abroad..

\section{Rights and Law}

Human rights implementation, advocacy and enforcement have led, no doubt, to improvements in the quality of life for many people in many different places. Human rights operate both to restrain the overbearing state through civil and political rights and, increasingly, to compel the delinquent state to provide for its citizens, through social and economic rights. This is by no means a completed project, and

\footnotetext{
${ }^{15}$ See John Ibbitson, “Mulroney's advice to Harper: Don't give up on the United Nations" The Globe and Mail (October 4, 2012). See also Paul Heinbecker, "It's not just the drought treaty. Canada is vanishing from the United Nations" The Globe and Mail (April 1, 2013). .

16 In the time passed since these remarks were delivered, Canada has withdrawn from an important international drought convention that will protect vulnerable people from the effects of climate change. See Mike Blanchfield, "Canada first country to pull out of UN drought convention" The Globe and Mail (March 27, 2013). Canada also refused to sign a new treaty designed to curb arms trading. See Stephanie Levitz, "Canada opts not to sign landmark arms-trade treaty for now" The Globe and Mail (June 3, 2013).

17 "UN review finds Canada falling short on child rights", The Canadian Press (October 10, 2012). Online: http://www.cbc.ca/news/politics/story/2012/10/10/pol-cp-united-nations-canada-childjustice.html. The report was referring to Bill C-10, the federal Safe Streets and Communities Act (received Royal Assent on March 13, 2012).

18 Ibid.
} 
the human rights movement itself has endured criticism for the limitations inherent in the promises and demands of human rights. ${ }^{19}$

Even optimists have been disappointed that, notwithstanding the success of rights on many fronts, acute challenges have at times led to the erosion of international human rights assurances. In particular, the post-9/11 decade has seen the rise of the paranoid and insecure state. Mature model democracies, like the United States, Canada and Britain, have been prone to excess, adopting practices such as rendition, preventative detention, aggressive interrogations and spying. Such practices have been carried out within domestic borders and against citizens, in addition to extrajudicial executions and illegal wars abroad. Most alarming is the foundational nature of the human rights issues back on the radar: habeas corpus; torture; murder. ${ }^{20}$ This is a sober reminder that, even in a robust rule-of-law system, we cannot take human rights for granted, nor be complacent about the impact of state action on the lives of individuals and communities.

Under the Canadian constitutional order, the courts are the final stop for justice, both in a substantive sense to the extent that they define and interpret the law, and in an institutional sense, given their inherent power and responsibility to uphold the rule of law. However, courts are somewhat constrained when it comes to applying international law, which is not binding in Canada unless it has been "implemented". ${ }^{21}$ The process for implementing international law usually comes after the government has signed and ratified a treaty. Ratification is the process by which formal authorization is given for the state to accede to an international convention. In Canada, unlike in the United States, ratification does not require legislative input; the executive can both sign and ratify treaties on the basis of Cabinet's democratic authority. Implementation, however, requires legislative action. In other words, to make an international human rights norm binding and justiciable in Canadian courts, legislators must write it into the statute books. ${ }^{22}$ The

19 See David Kennedy, “The International Human Rights Movement: Part of the Problem?” (2002) 15 Harv Hum Rts J 101.

20 For example, a closed-door inquiry headed by former Supreme Court of Canada Justice Frank Iacobucci found that Canada was indirectly responsible for the torture of three Muslim-Canadian men. In another case, the government paid $\$ 10$ million in compensation to Maher Arar after a public inquiry found that Canadian security officials had given false information that led to his rendition to torture in Syria. See generally Kent Roach, The 9/11 Effect: Comparative Counter-Terrorism (New York: Cambridge U Press, 2011).

21 Amissi M Manirabona and François Crépeau, "Enhancing the Implementation of Human Rights Treaties in Canadian Law: The Need for a National Monitoring Body" (2012) 1:1 Can J Hum Rts 25.

22 In some countries, the final step of implementation is not required. In such states, international treaties duly ratified by the Executive gain the force of law without the requirement of any domestic legislative action. Historically, France is the model monist state. The Westminster system of government has typically required independent legislative action to make international law binding, though this is changing. Under the 2010 Constitution of Kenya, for example, automatic incorporation of international law is provided. See Constitution of Kenya (adopted 27 August, 2010), Article 2 (5) 
vast majority of the content of international human rights law has not been incorporated into Canadian law. ${ }^{23}$

While Canada has not directly incorporated much international human rights law, international human rights norms are not absent from Canadian law. The Canadian Charter of Rights and Freedoms, together with statutory human rights instruments, ensures that many key international human rights norms are enshrined in Canadian law. Thus, domestic Canadian law provides a reasonably robust array of legal protections that roughly mirrors many of the key rights in the canonical instruments of international human rights law.

One notable exception with respect to implementation is the International Criminal Court. Although the ICC is not technically a human rights body within the United Nations framework, it is certainly an institution associated with the human rights aspirations of its time. When the Rome Statute was signed in 1998, Canada was a world leader in the international political campaign to establish a permanent court to prosecute war crimes and crimes against humanity. In order to ratify the Rome Statute, Canada's Parliament was first required to enact legislation to implement its obligations under the law. Canada was the first country in the world to incorporate the Rome Statute into its national laws, enacting the Crimes Against Humanity and War Crimes Act on June 24, 2000, and ratifying the Rome Statute two weeks later.

The political consensus around the establishment of the ICC was, in many ways, not surprising, given Canada's past commitment to world peace-building. It also reflected an acknowledgement that the atrocities of the Second World War form part of the rationale behind Canada's human rights commitments. In 1987, the thenChief Justice of the Supreme Court of Canada, Brian Dickson, wrote a thoughtful dissent in a case about labour associational rights under the young Charter. Commenting on the history of international human rights and its place in the Canadian constitutional order, he wrote:

Since the close of the Second World War, the protection of the fundamental rights and freedoms for groups and individuals has become a matter of international concern. A body of treaties (or conventions) and customary norms now constitutes

and (6) providing that "general rules of international law" and "any treaty or convention ratified by Kenya" are part of national law.

${ }^{23}$ Canada has signed and ratified seven key international human rights instruments: International Covenant on Civil and Political Rights; the International Covenant on Economic, Social, and Cultural Rights; the International Convention on the Elimination of All Forms of Racial Discrimination; the Convention on the Elimination of All Forms of Discrimination Against Women; the Convention Against Torture and Other Cruel, Inhuman, or Degrading Treatment or Punishment; and the Convention on the Rights of the Child; and the Convention on the Rights of Persons with Disabilities. Canada has also signed the optional protocols allowing for individual complaints by persons under Canadian jurisdiction with respect only to CEDAW and the ICCPR. 
an international law of human rights under which the nations of the world have undertaken to adhere to the standards and principles necessary for ensuring freedom, dignity and social justice for their citizens. The Charter conforms to the spirit of this contemporary international human rights movement, and it incorporates many of the policies and prescriptions of the various international documents pertaining to human rights. The various sources of international human rights law -- declarations, covenants, conventions, judicial and quasi-judicial decisions of international tribunals, customary norms -- must, in my opinion, be relevant and persuasive sources for interpretation of the Charter's provisions. ${ }^{24}$

There have been surprisingly few instances of direct application or interpretation of international human rights law in Canadian courts. An important decision that built on the ideas expressed by Dickson CJ can be found in the 1999 Baker decision. ${ }^{25}$ Although the Supreme Court of Canada unanimously confirmed that unincorporated international law is not directly applicable or binding in Canadian courts, five of the seven sitting judges accepted that unincorporated international law-whether customary norms or treaties-should be recognized as an interpretive aid when applying relevant Canadian law.

The Baker case involved an administrative decision by immigration officials to deny the appellant, a long-time irregular resident of the country, an exemption from a mandatory deportation order. The basis for her humanitarian and compassionate grounds request included, among other considerations, the fact that she was a single mother with several Canadian-born children. She argued that the doctrine of the "best interests of the child", enshrined in the Convention on the Rights of the Child, was a factor necessary for government officials to consider when exercising their powers under domestic immigration legislation. The majority agreed that the "principles of the Convention and other international instruments place special importance on protections for children and childhood, and on particular consideration of their interests, needs, and rights." 26 The Court also noted that other common law countries, including New Zealand and India, have embraced the role of international human rights law as an aid in interpreting domestic law, even if not directly enforceable.

If the rights of children earned a robust role for international human rights in domestic jurisprudence, the events of 9/11 and the rights of suspected "terrorists" brought a different tenor to the issue when the Supreme Court of Canada considered

\footnotetext{
${ }^{24}$ Reference Re Public Service Employee Relations Act (Alta.) [1987] 1 SCR 313 at para 57.

${ }^{25}$ Baker v Canada (Minister of Citizenship and Immigration), [1999] 2 SCR 817.

26 Ibid at para 71 .
} 
the case of Suresh. ${ }^{27}$ In that decision, rendered in early 2002, the Court refused to permit the deportation of a man-a Tamil activist-who might face torture on return to his country of origin, Sri Lanka. The Court applied the International Convention Against Torture (CAT) in a supporting role to section 7 of the Charter, which guarantees life, liberty and security of the person, deprivations of which must be in accordance with principles of fundamental justice. Reasoning in the context of national security, the Court considered the state of international law with respect to torture: "In our view, the prohibition in the ICCPR and the CAT on returning a refugee to face a risk of torture reflects the prevailing international norm." ${ }^{28}$ It went on to hold that this norm shapes the content and interpretation of the principles of fundamental justice under section 7. The Court also used reasoning based on comparative jurisprudence, noting that the highest courts of Israel and the UK have held that international law rejects deportation to torture, even where national security interests are at stake. ${ }^{29}$

Five years after Suresh, the Supreme Court had another occasion to consider international law in the context of immigration and national security law ${ }^{30}$ when three appellants, Adil Charkaoui, Mohamed Harkat and Hassan Almrei, challenged the constitutionality of an administrative detention scheme that had left each of them in legal limbo: incarcerated but not charged; suspected of being a security threat, but not told on what basis or for what reason; and offered opportunities to challenge the reasonableness of the detention, but denied information necessary to know the case to be met. ${ }^{31}$ Again, applying section 7 of the Charter, the Court held that it was a violation of fundamental justice detain arbitrarily and not to have a detention review in a reasonable time. Unlike in Suresh, however, the case was decided primarily with reference to Canadian constitutional law, and with no consideration of international human rights law, notwithstanding that the parties and numerous amicus interventions highlighted international legal dimensions.

Although neglecting international law, the Court in Charkaoui did show an interest in comparative jurisprudence, referring to the European Convention on Human Rights and to the reasoning of the European Court of Human Rights, the United States Supreme Court and the United Kingdom House of Lords in similar cases, for a comparative analysis about detention and national security. ${ }^{32}$ While it may not be true that the Court has receded in its view of international human rights, it does appear that the sway of international human rights law in Canadian jurisprudence

\footnotetext{
27 Suresh v Canada (Minister of Citizenship and Immigration) [2002] 1 SCR 3

${ }^{28}$ Ibid at para 72.

${ }^{29}$ Ibid at para 74 .

${ }^{30}$ Charkaoui v Canada (Citizenship and Immigration) [2007] 1 SCR 350.

31 The instrument by which non-citizens may be administratively detained without charge is known as the "security certificate", pursuant to section X of IRPA.

${ }^{32}$ Charkaoui supra at paras 90, 125-127.
} 
remains cautious. In a lecture on the state of Canadian Confederation, the current Chief Justice of the Supreme Court of Canada stated that international norms are relevant to judging the constitutionality of laws and government action, and "may affect the duties of government decision makers." 33

\section{Access to International Fora, Access to Justice?}

International law has traditionally operated on the basis that states are the citizens of the world community; people tended to be viewed as objects of international law, rather than subjects of it. Indeed, international treaties and rules were derived from states agreeing with one another or adopting similar practices, and international institutions were the mechanisms of cooperation and accountability between states. However, if we view international law as offering a prototypical structure for global citizenship of people, not just states, then we can begin to see the emergence of a global rule of law that is not only concerned with protecting states' interests vis-àvis one another and their citizens, but also with an independent mandate to protect individuals and groups.

The statist approach to international relations and, in particular to international law, is, and will continue to be, subject to a growing set of pressures and challenges. New sites of action have emerged, with non-state players mobilizing on many fronts to seize power in the international order. For example, the size and influence of transnational corporations has led to inroads in global corporate regulation and "social responsibility". ${ }^{34} \mathrm{~A}$ significant impetus for applying an ethic-if not an obligation-of rights compliant behaviour on corporations is the very real impact that corporate activity has on people's lives, especially in a globalized world.

Thus, while formally, states are the citizens of the international community, human beings are increasingly the subjects of the UN's mandate. This notion was envisaged at the UN's birth-the Charter is proclaimed in the name of the "peoples of the United Nations", notwithstanding that the UN governing bodies are constituted of states, without any condition that the state be democratically representative of its population. Nonetheless, the Charter contains the normative core of the international human rights movement, affirming "faith in fundamental human rights, in the dignity and worth of the human person, in the equal rights of men and women and of nations large and small". The promise of the UN Charter, and of the human rights law established under its auspices, is in a very practical sense conditional on the ability to access justice at the international level. Experience

\footnotetext{
33 "Remarks of the Right Honourable Beverley McLachlin, P.C. Chief Justice of Canada" Symons Lecture (2008). Full text online: http://www.scc-csc.gc.ca/court-cour/judges-juges/spe-dis/bm2008-10-21-eng.aspx.

${ }^{34}$ See United Nations Guiding Principles on Business and Human Rights (endorsed by UN Human Rights Council, June 16, 2011). This was the culmination of the work of Professor John Ruggie, Special Representative of the UN Secretary-General on the issue of human rights and transnational corporations and other business enterprises, from 2005-2011.
} 
proves that whether dealing with international institutions or instruments, the challenges to access to justice remain foundational and pervasive. ${ }^{35}$

In December 2006 the Convention on the Rights of Persons with Disabilities was endorsed by the UN General Assembly. It opened for signature by states on March 30, 2007-Canada signed it immediately. The Convention came into force on May 3, 2008 after being ratified by 20 countries-Canada was not among them, waiting nearly two years to finally ratify the Convention, on March 11, 2010.36 The Disability Convention reflects the culmination of 30 years of disability inroads at the UN, beginning with the International Year of Disabled Persons in 1981. Reflecting the evolution of an international consensus on the fundamental rights of people with disabilities, the Convention stresses the importance of accessibility, participation and inclusion, education, health, employment, and social welfare. It straddles and integrates both civil and political, and social and economic, rights.

The Convention further affirms the protection from discrimination through the tools of reasonable accommodation and affirmative action, the main drivers of equality for people with disabilities. ${ }^{37}$ It also justifies the use of affirmative action programmes. As a signatory, Canada has obligations to report to the Committee established under the Convention. However, reporting is a weaker enforcement tool than the individual complaints mechanism. If Canada were to sign on to the Optional Protocol, it would extend an additional right of access for Canadians who have exhausted internal avenues of redress to seek international access to justice. ${ }^{38}$ In June 2012, the Canadian Senate Standing Committee on Human Rights, led by Senator Mobina Jaffer, issued a report on sports and disability, making a strong call for the government to sign and ratify the Optional Protocol immediately, so as to give Canadians access to the Disability Convention's individual rights complaints process. ${ }^{39}$ As of yet, there is no indication that the government intends to adopt Senator Jaffer's recommendation.

Access to international fora for Canadians with human rights grievances is one way to promote government accountability for domestic application of international

\footnotetext{
${ }^{35}$ See Francesco Francioni, ed., Access to Justice as a Human Right (Oxford: Oxford U Press, 2007).

36 UN Enable, Secretariat for the Convention on the Rights of Persons with Disabilities (SCRPD). Online: http://www.un.org/disabilities/countries.asp?navid=12\&pid=166

${ }^{37}$ Disability Convention, Art. 5(2), (3) and (4).

${ }^{38}$ Complaints procedures are established under the International Covenant on Civil and Political Rights, the Convention Against Torture Convention Against Torture, the International Convention on the Elimination of All Forms of Racial Discrimination, the Convention on the Rights of Persons with Disabilities and the Convention on the Elimination of All Forms of Discrimination Against Women. Canada has, so far, only signed on to the complaints process under CEDAW and the ICCPR.

${ }^{39}$ Standing Senate Committee on Human Rights, Level the playing field: A natural progression from playground to podium for Canadians with disabilities, The Honourable Mobina S. B. Jaffer, Chair (June 2012). Online: http://www.parl.gc.ca/Content/SEN/Committee/411/ridr/rep/rep07jun12-e.pdf.
} 
human rights norms. At the same time, under existing avenues, it is not clear that the ability to bring a claim will necessarily influence state action domestically. The potential influence that such access would ultimately wield is an open question.

Considering Canada's track record with individual complaints to UN bodies, guarded optimism is in order. Consider the 2004 case of Nuri Jazairi. An economics professor at York University in Toronto, Jazairi initiated a complaint with the Human Rights Committee challenging the failure of Ontario's human rights legislation to include protection for "political opinion". He had been denied tenure, and believed that the university's decision was discriminatory on the basis of his outspoken political views. He also made other charges against alleged inadequacies in the province's anti-discrimination legislation, which Jazairi argued constituted a breach of the nondiscrimination provisions in the Covenant. ${ }^{40}$

The case made its way to the Court of Appeal for Ontario, where the Court held that political opinion is not generally protected under the Human Rights Code, and that even if it were, the appellant had failed to establish a factual link between his political opinions and the university's decision to deny him tenure. Given this, the Committee would not interfere with the Canadian courts' decision on the facts. In dismissing the case, the majority of the panel nonetheless expressed concern that the "absence of protection against discrimination on [the ground of political opinion] does raise issues under the Covenant." 41

Two years after Jazairi was decided by the Human Rights Committee, Ontario began a major overhaul of its human rights system and in 2007, a new law was adopted. Notably absent was any addition of "political opinion" as a new ground of protection. Surprising in the deliberations leading up to the adoption of the new Code was the virtual absence of considerations of international human rights law, the gaps between the ICCPR and domestic legislation, or the opinions expressed by the Committee in the Jazairi decision.

\section{Conclusion}

The Canadian approach to human rights remains primarily a domestic approach. However, with changes in legal education and the rapid globalization of the law, especially relevant to younger lawyers and legal researchers, we can expect to see a measured increase in the profile of international human rights law in Canadian courts. Certainly, law librarians in this country have been a tremendous (and underutilized) resource for accessing international human rights material and comparative jurisprudence. Better coordination at all levels between lawyers, research librarians and scholars might help to accelerate the pace and deepen the influence of international human rights law, enabling it to assume a more prominent

${ }^{40}$ Jazairi v Ontario Human Rights Commission (1999), 175 DLR (4th) 302 (Ont CA).

${ }^{41}$ Nuri Jazairi v Canada, Communication No. 958/2000, U.N. Doc. CCPR/C/82/D/958/2000 (2004). 
place-in a meaningful and actionable sense-at the heart of Canadian law and policy. 